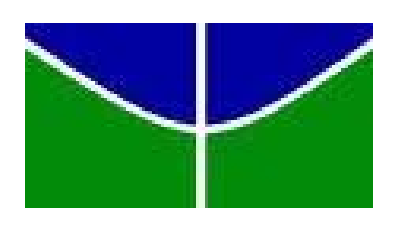

\author{
UNIVERSIDADE DE BRASÍLIA \\ Faculdade de Educação UAB/UnB/MEC/SECAD \\ Curso de Especialização em Educação na Diversidade e \\ Cidadania, com Ênfase em EJA
}

JOSÉ SIDNEY DA SILVA

O ENSINO DE GEOGRAFIA NA EJA:

Adequabilidades dos Conteúdos À Vivência dos Alunos 


\author{
JULHO/2010 \\ UNIVERSIDADE DE BRASÍLIA \\ Faculdade de Educação UAB/UnB/MEC/SECAD \\ Curso de Especialização em Educação na Diversidade e \\ Cidadania, com Ênfase em EJA
}

\title{
O ENSINO DE GEOGRAFIA NA EJA: \\ Adequabilidades dos Conteúdos À Vivência dos Alunos
}

José Sidney da Silva

Professor orientador: Professor Doutor Renato Hilário dos Reis

Tutora orientadora: Leila Maria de Jesus Oliveira

Projeto de Intervenção Local

Brasília, DF julho /2010 


\section{UNIVERSIDADE DE BRASÍLIA \\ Faculdade de Educação UAB/UnB/MEC/SECAD \\ Curso de Especialização em Educação na Diversidade e Cidadania, com Ênfase em EJA}

JOSÉ SIDNEY DA SILVA

\section{O Ensino de Geografia Na EJA:}

Adequabilidade dos conteúdos à Vivência dos alunos

Projeto de Intervenção Local (PIL) apresentado ao programa de Pós-graduação Lato Sensu em Educação na Diversidade e Cidadania, com ênfase em EJA, da Universidade de Brasília (UNB), no âmbito da Universidade Aberta do Brasil (UAB) como parte dos requisitos necessários para obtenção do grau de Especialista na Educação de Jovens e Adultos.

Dr. Renato Hilário

Professor Orientador

Me. Leila Maria de Jesus Oliveira

Tutora Orientadora

Avaliador Externo: Cláudia Denis Alves da Paz 
Dedico este trabalho aos meus pais, esposa, filhos e a todos que de alguma forma contribuíram para a conclusão de mais uma etapa em minha formação. 


\section{AGRADECIMENTOS}

Agradeço em especial a Deus, pelas bênçãos e proteção a mim concedidas.

Agradeço ainda, aos meus amados pais, filhos e a minha querida esposa (Dalma Menezes da Silveira ) pelo apoio dado nesta caminhada.

E por fim, agradeço a minha Tutora Orientadora: Leila Maria de Jesus Oliveira. 
A alegria não chega apenas no encontro do achado, mas faz parte do processo da busca. E ensinar e aprender não pode dar-se fora da procura, fora da boniteza e da alegria.

Paulo Freire 


\section{RESUMO}

Este projeto de intervenção local (PIL), busca identificar as dificuldades apresentadas dentro e fora de sala de aula, quanto a adequabilidades dos conteúdos de Geografia aplicadas às turmas de Educação de Jovens e Adultos (EJA). Tenta-se aqui, buscar formas alternativas de se trabalhar a disciplina, tornando-a mais atrativa e prazerosa para os professores e alunos. Nele, não se pretende fornecer conteúdos e metodologias prontas e acabadas, dadas as especificidades e a liberdade criativa de cada público envolvido. Mas apenas refletir e quem saber intermediar novas abordagens que visem facilitar a contextualização dos conteúdos em atividades práticas. Para isso, traz dados coletados a partir de questionários, observações e conversas feitas em sala de aula com alunos, professores, demais membros da comunidade escolar, bem como informações necessárias às reflexões sobre o tema abordado; Referenciais utilizados como fonte de ajuda e pesquisa, importantes para o acompanhamento da leitura e também para possíveis estudos.

Palavras chaves: Educação de Jovens e Adultos, Contextualização, Geografia, Adequabilidade, Especificidades. 


\section{SUMÁRIO}

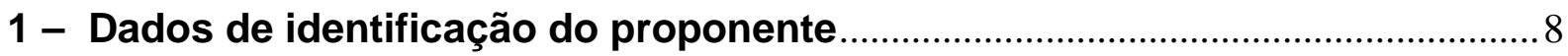

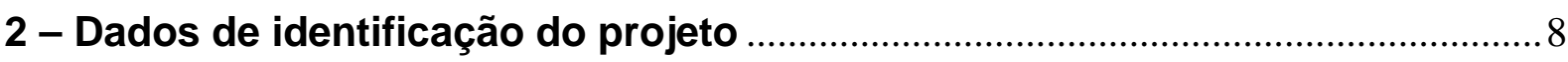

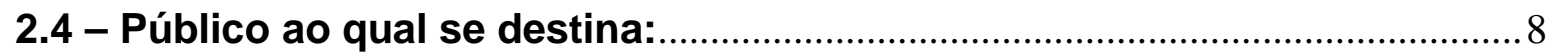

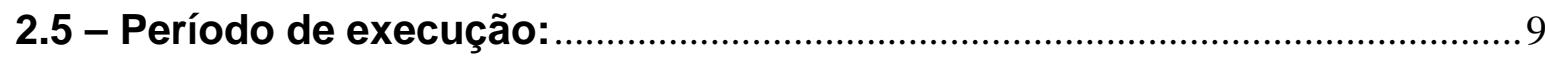

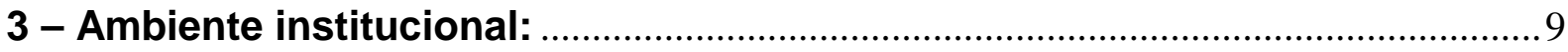

4 - Justificativa e caracterização do problema.........................................................19

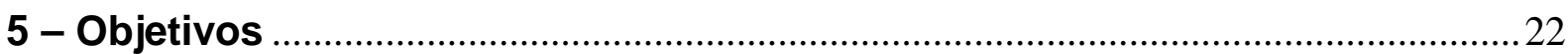

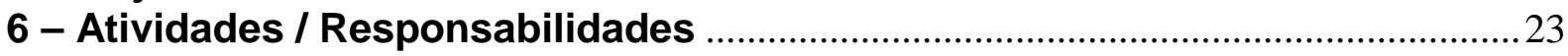

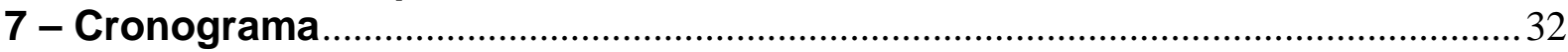

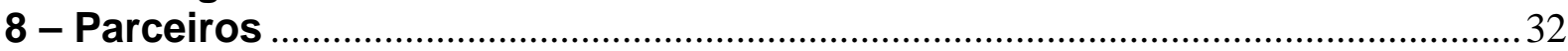

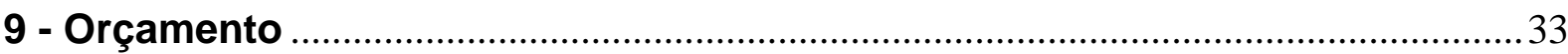

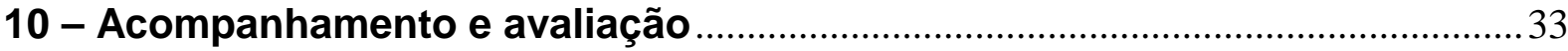

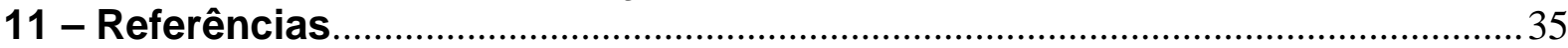

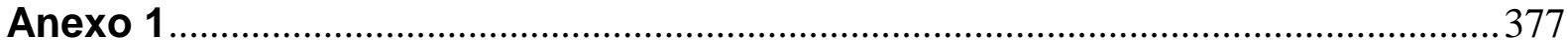

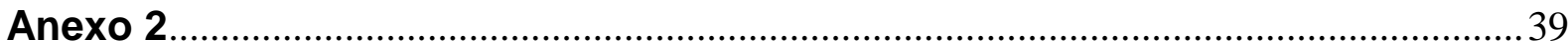




\section{1 - Dados de identificação do proponente}

\section{1 - José Sidney da Silva}

1.2 - EJA (Educação de Jovens e Adultos)

$2^{\circ}$ segmento.

1.3 - Informações para contato:

Telefones: 33843844 (R) 84752015 (C)

e-mail : josesidney@bol.com.br

\section{2 - Dados de identificação do projeto}

2.1 - O Ensino de Geografia na EJA: Adequabilidade dos Conteúdos à Vivência dos Alunos

2.2 - Área de abrangência:

Local: Centro de Ensino Fundamental 10 do Gama.

2.3 - Instituição:

Centro de Ensino Fundamental 10 do Gama.

End.: EQ. 19/22 e 16/26 Área Especial

Setor Oeste - Gama, DF.

Instância institucional de decisão:

SEEDF (Secretaria de Estado de Educação do DF)

Regional de Ensino do Gama

Centro de Ensino Fundamental 10 do Gama

\section{4 - Público ao qual se destina:}

Características básicas do público alvo

Alunos e professores da EJA, turno noturno, do $2^{\circ}$ segmento, que funciona exclusivamente com ensino fundamental. Público composto por jovens, adultos e idosos aos quais interromperam seu percurso escolar, conforme explicitado no art. 37 da Lei de Diretrizes e Bases da Educação: "A Educação de Jovens e Adultos destina-se àqueles que não tiveram acesso ou continuidade de estudo no ensino fundamental e médio na idade própria", bem como segundo entendimento da VI CONFITEA (2009), jovens e adultos trabalhando e aprendendo ao longo da vida.

Grande maioria, conforme tabelas em anexo, composta por trabalhadores de baixa renda, com excesso de horas trabalhadas e que gastam muito tempo com condução, também composta por aposentados, donas de casa, jovens desempregados, estagiários, servidores públicos civis e militares. Há ainda alunos portadores de necessidades educacionais especiais. 


\section{5 - Período de execução:}

08/2010 a 11/2010

\section{3 - Ambiente institucional:}

A Unidade Pública de Ensino será o Centro de Ensino 10 do Gama, localizado na E/Q 19/22 Área Especial - Setor Oeste do Gama. Criado em 09/10/1977 com a finalidade de atender alunos da modalidade regular e de Educação de Jovens e Adultos, distribuídos entre os turnos matutino, vespertino e noturno. Disponibiliza-se para isso, de 17 salas de aula, uma sala de coordenação, uma para Orientação Educacional, uma de apoio, duas para a direção, uma de multimídia, uma para os professores, uma Biblioteca, almoxarifado, Administrativo e Secretaria. Especificamente à noite conta com um coordenador geral, um administrativo, um supervisor pedagógico, um orientador educacional, um auxiliar de secretaria, dois porteiros e quinze professores distribuídos por disciplinas conforme tabela abaixo:

\begin{tabular}{c|c}
\hline Componente Curricular & Número de professores \\
\hline Português & 04 \\
\hline Matemática & 04 \\
\hline Ciências & 03 \\
\hline História & 02 \\
\hline Geografia & 02 \\
\hline Ed. Física & 02 \\
\hline LEM- & 02 \\
\hline Artes & 02 \\
\hline
\end{tabular}

Fonte: Quadro de Distribuição de Disciplina do Centro de Ensino Fundamental 10 do Gama - 2010

Verificaremos até que ponto a maioria dos alunos da Educação de Jovens e Adulto está sendo prejudicada em função da inobservância de aspectos que podemos considerar imprescindíveis para o desenvolvimento de um bom ensino e aprendizado. Diante disso, fezse necessário inicialmente, traçarmos o perfil destes alunos que freqüentam a Educação de Jovens e Adultos, sendo clara a importância de um levantamento para que possamos avaliar as motivações principais que os levam ao ensino noturno, suas dificuldades, seus interesses e anseios. Acredito que de posse desta pesquisa realizada neste PIL, tais informações servirão se necessário, de instrumentos na concepção de novas formas de abordagens dos conteúdos programáticos e metodologias pedagógicas adaptadas às especificidades dos mesmos.

Logo, o público alvo é representado por alunos compreendidos entre a faixa etária de 15 a 60 anos de idade. A maioria do sexo feminino, distribuídos em dez turmas de 5a/8a séries. Trabalhadores do setor informal de baixa renda, em sua maioria sem carteira assinada (domésticas, vigias, camelôs, balconista e aposentados), muitos residindo nas proximidades da escola; nordestinos ou filhos de nordestinos vivendo a mais de 10 anos no 
DF, tempo este, suficiente para já terem concluído o $1^{\circ}$ Grau e que procuram o ensino de Educação de Jovens e Adultos pela perspectiva de melhoria de vida, de ascensão social, econômica e profissional, pela via da educação, seja por uma necessidade do trabalho que exerce, seja pelas condições gerais de vida futura, seja pura e simplesmente para melhorar o salário.

Segundo Cordeiro (1.984, p. 103),

"alunos trabalhadores confiam na escola como um meio de realização profissional, o que inclui promoção e um lugar de destaque, ainda que relativo na estrutura ocupacional".

Através das conversas informais feitas em sala de aula, dos questionários e das entrevistas feitas com os alunos do Centro de Ensino Fundamental 10 do Gama, verificou-se que a ascensão profissional destes alunos pode estar ligada à questão da melhoria salarial. O fator econômico para estes alunos que recebem no máximo dois salários mínimos tornase o incentivo principal que os fazem retornar à sala de aula. Muitos pretendem mediante a escolarização, conseguir empregos melhores e menos cansativos em escritórios ou firmas comerciais. Sonham talvez com profissões liberais e também passar em concursos públicos, muito freqüentes no DF. Além disso, segundo relato de um professor do noturno, o aluno que precisa trabalhar é geralmente visto como um "esforçado", "sacrificado" que não tem bom rendimento por falta de tempo e que precisa estudar para se promover no trabalho e tem como crença a Educação como instrumento de ascensão social.

A maioria parece ser levado pela perspectiva da melhoria de vida, de ascensão econômica e profissional pela educação. Salário, a promoção, a esperança de uma vida melhor através de um emprego que ganhe mais, configuram a perspectiva de subir na vida tendo a educação como motora. (Cordeiro 1984, p. 103 e 104).

Segundo Weber (1076, p. 107):

"Em suma quer como motivação social ou individual, a escolaridade obrigatória esta sempre associada com o desejo de um certo conforto material, a uma certa facilidade no trabalho, graças à educação."

Apresento a seguir tabela 1 que trata da distribuição dos alunos do $2^{\circ}$ segmento no Centro de Ensino 10 do Gama - segundo a Faixa Etária e Sexo: 


\begin{tabular}{l|c|c|c}
\hline \multicolumn{1}{c|}{ IDADE } & HOMENS & MULHERES & TOTAL \\
\hline $15 \vdash 26$ & 14 & 24 & 38 \\
\hline $27 \vdash 37$ & 06 & 10 & 16 \\
\hline $38 \vdash 48$ & 03 & 07 & 10 \\
\hline 48 a mais & 08 & 07 & 15 \\
\hline S/Docum. & 03 & 08 & 11 \\
\hline TOTAL & 34 & 57 & 91 \\
\hline
\end{tabular}

Fonte: Centro de Ensino Fundamental 10 do Gama.

De acordo com os números apresentados podemos verificar que a maioria dos alunos de primeiro grau do Centro de Ensino 10 do Gama, é de jovens compreendendo entre 15 e 24 anos de idade. É praticamente menor a presença de alunos com mais de 38 anos na Educação de Jovens e Adultos. Possivelmente, a justificativa para isto, esteja no fato de que alunos mais jovens, motivados por uma melhoria de vida, possuam uma perspectiva temporal maior quanto à ascensão funcional através dos estudos.

Os mais velhos não pensam em estudar para obterem ascensão funcional, mas sim para a auto-estima e adquirir conhecimento. Quanto ao sexo, nota-se uma maior proporção de moças, isso pode ser explicado pelo número de empregadas domésticas que cursam a Educação de Jovens e Adultos.

Tabela 2 - Ocupação dos Alunos do Centro de Ensino Fundamental 10 do Gama

\begin{tabular}{c|c}
\hline OCUPAÇÃO & $(\%)$ \\
\hline Comércio (balconista, mercadinho) & 33 \\
\hline Camelô (ambulante e feirante) & 14 \\
\hline Construção Civil & 10 \\
\hline Oficina Mecânica & 07 \\
\hline Emprego Doméstico & 12 \\
\hline Segurança (militar, vigia) & 05 \\
\hline Indústria & 03 \\
\hline Não Trabalham & 16 \\
\hline
\end{tabular}

Fonte: Secretaria do Centro de Ensino Fundamental 10 do Gama.

Existe uma elevada presença de alunos trabalhadores, evidenciado no quadro acima. Sobre a ocupação, muitos alegam ter ingressado no mercado de trabalho precocemente, tendo grande parte deles, situação trabalhista ainda precária e desqualificada, além de baixos salários, sem carteiras assinadas e trabalhando mais de 8 horas diárias. Quanto ao tipo de ocupação desses alunos, segundo pesquisa feita na Secretaria da Escola, há uma concentração no setor terciário, haja vista não possuírem pré-requisitos para empregos que exijam mão-de-obra especializada, vigente no setor secundário. 
Na conclusão de (chaves, 1986 p.72):

J mesmo observa que o setor terciário não só concentra quase que a totalidade dos alunos como apresenta uma continuidade entre os mesmos, absolutamente superior à verificada no setor secundário".

O crescimento das atividades terciárias nas economias subdesenvolvidas é resultante da absorção de mão-de-obra de baixos níveis de produtividade, devido à liberação de trabalhadores das atividades agrícolas (nordeste), por exemplo, e a sua absorção na indústria (Carvalho, 1984 p.43).

Tabela 3 - Renda Mensal dos Alunos do Centro de Ensino Fundamental 10 do Gama

\begin{tabular}{c|c}
\hline SALÁRIO & $(\%)$ \\
\hline TOTAL & 100 \\
\hline Até 1 & 40 \\
\hline De 1 Até 2 & 28 \\
\hline Acima de 2 até 4 & 14 \\
\hline Acima de 6 até 8 & 60 \\
\hline Acima de 8 até 12 & 51 \\
\hline
\end{tabular}

Fonte: Ficha de Matricula - SOMA - Secretaria do Centro de Ensino 10 do Gama.

Podemos verificar nas tabelas anteriores que um número expressivo de alunos tem sua atividade econômica ligada ao comércio, tanto no que diz respeito ao terciário, formal como informal. O nível de renda é baixo, 68\% dos alunos ganham até 2 salários mínimos, pegam ônibus, pagam a condução, o almoço e aluguel e às vezes, mesmo sendo solteiros contribuem na renda familiar de seus lares.

Tabela 4 - Local de trabalho dos alunos do Centro de Ensino Fundamental 10 do Gama.

\begin{tabular}{c|c}
\hline LOCAL DE TRABALHO & $(\%)$ \\
\hline Ceilândia & 1 \\
\hline Cruzeiro & 4 \\
\hline Entorno & 2 \\
\hline Gama & 30 \\
\hline Guará & 3 \\
\hline Núcleo Bandeirante & 6 \\
\hline Taguatinga & 4 \\
\hline Plano Piloto & 50 \\
\hline
\end{tabular}

Fonte: Ficha da Secretaria do Centro de Ensino 10 do Gama.

Duas grandes percentagens aparecem como significativas: a dos alunos que trabalham na mesma localidade onde estudam 30\% no Gama, a dos que trabalham no 
Plano Piloto $50 \%$ que é a região de maior oferta de trabalho. Este dado se torna importante na medida em que se pode verificar a necessidade do trajeto trabalho, escola e casa. Gama é uma das cidades Satélites mais distantes do DF, 38 km, onde se leva cerca de 60 minutos em transporte público de viagem entre o Plano Piloto e a referida cidade. Este é um dado a considerar, já que os alunos estudam à noite, depois de uma jornada de trabalho e viagem até a escola e tal dispêndio de energia interfere no rendimento, no processo ensino aprendizagem.

Tabela 5 - Distância das cidades satélites em relação ao Plano Piloto.

\begin{tabular}{c|c}
\hline Cidades Satélites e o Plano Piloto & $(\mathrm{KM})$ \\
\hline Guará & 13 \\
\hline Núcleo Bandeirante & 12 \\
\hline Taguatinga & 25 \\
\hline Ceilândia & 35 \\
\hline Gama & 38 \\
\hline Sobradinho & 22 \\
\hline Planaltina & 40 \\
\hline Brazlândia & 43 \\
\hline
\end{tabular}

Fonte: Gonzalez, Suely F. N - A estratificação Residencial Urbana no caso de Brasília, Porto Alegre, UFRGS 1979, p.39.

Tabela 6 - Motivação dos alunos do Centro de Ensino Fundamental 10 do Gama para continuar os estudos.

\begin{tabular}{c|c}
\hline Motivos & $(\%)$ \\
\hline Ascensão profissional, melhoria de vida/salário & 80 \\
\hline Ampliação de conhecimentos, necessidades de aprendizagem & 12 \\
\hline Deixar de ser explorado e ter opinião crítica & 6 \\
\hline Fazer Amizade & 3 \\
\hline
\end{tabular}

Fonte: Questionários dirigidos aos alunos do Centro 10 do Gama.

Aqui, os dados revelam $80 \%$, sem sombra de dúvida que o interesse maior é a ascensão profissional, obviamente ligada à questão da melhoria salarial. O fator econômicos para estes alunos que recebem no máximo 2 salários mínimos torna-se o incentivo principal que o fazem retornar à sala de aula.

Segundo Cordeiro (1984. P. 103 e 104):

"Alunos trabalhadores ou não confiam na escola como um meio de realização profissional, o que inclui promoção e um lugar de destaque na estrutura operacional. Incorpora-se, pois, a ideologia que lhe repassam, quando à escola atribuem a via mais provável para a escalada profissional, muito embora, assim como os seus próprios limites enquanto possibilidade" 
Tabela 6 - Escolaridade exigida para as atividades executadas no trabalho dos alunos do Centro de Ensino Fundamental 10 do Gama.

\begin{tabular}{c|c}
\hline ESCOLARIDADE & $(\%)$ \\
\hline $3^{a}$ Série & 40 \\
\hline $4^{a}$ Série & 35 \\
\hline $5^{a}$ Série & 25 \\
\hline
\end{tabular}

Fonte: Questionários dirigidos aos alunos do Centro de Ensino 10 do Gama - 2010.

Verifica-se que grande parte dos alunos do Centro de Ensino Fundamental 10 do Gama - necessita de conhecimentos referentes ao Ensino Fundamental, para desempenharem melhor suas atividades no emprego e dada às características do mercado de trabalho, muitos pretendem mediante escolarização, conseguir empregos melhores em escritórios, lojas comerciais ou até atingir profissões liberais.

Dados do público pesquisado - Alunos da Educação de Jovens e Adultos Centro de Ensino Fundamental de $1^{\circ} \mathrm{Grau} 10$ do Gama.

Amostra de 10 alunos do $2^{\circ}$ segmento

\begin{tabular}{|c|c|c|c|c|c|}
\hline $\begin{array}{l}\text { Perguntas/ } \\
\text { Entrevistados }\end{array}$ & 1 & 2 & 3 & 4 & 5 \\
\hline $\begin{array}{l}\text { 1) Qual a } \\
\text { escolaridade } \\
\text { necessária para } \\
\text { você executa a sua } \\
\text { profissão }\end{array}$ & Talvez $8^{\mathrm{a}}$ série & $\begin{array}{c}\text { Acho que } 6^{a} \\
\text { série. }\end{array}$ & $4^{\mathrm{a}}$ série & $5^{a}$ série & $6^{a}$ série \\
\hline $\begin{array}{l}\text { 2) Você acha que a } \\
\text { sua experiência de vida } \\
\text { pode contribuir nas } \\
\text { aulas de geografia em } \\
\text { sala de aula? }\end{array}$ & $\begin{array}{l}\text { Sim, mas não } \\
\text { sei explicar. }\end{array}$ & $\begin{array}{l}\text { O que aprendi } \\
\text { na outra série. }\end{array}$ & $\begin{array}{c}\text { Meus } \\
\text { conhecimentos } \\
\text { da roça. }\end{array}$ & $\begin{array}{c}\text { Não tenho o que } \\
\text { falar }\end{array}$ & $\begin{array}{c}\text { Agente ensina } \\
\text { muitas coisas aos } \\
\text { jovens }\end{array}$ \\
\hline $\begin{array}{c}\text { 3) Você costuma } \\
\text { utilizar o que você } \\
\text { aprende em } \\
\text { geografia no seu dia- } \\
\text { a-dia? }\end{array}$ & $\begin{array}{l}\text { Nem sempre, } \\
\text { mexo com } \\
\text { mercadorias }\end{array}$ & $\begin{array}{c}\text { Agente } \\
\text { entende os } \\
\text { jornais, } \\
\text { Esportes. }\end{array}$ & $\begin{array}{l}\text { Conversando } \\
\text { com os amigos }\end{array}$ & Não. & $\begin{array}{c}\text { Não, só quero } \\
\text { passar. }\end{array}$ \\
\hline $\begin{array}{c}\text { 4) Qual é a sua } \\
\text { profissão? Quanto } \\
\text { tempo está } \\
\text { empregado? }\end{array}$ & $\begin{array}{l}\text { Sou ambulante } \\
\text { há três anos. }\end{array}$ & $\begin{array}{l}\text { Trabalho em } \\
\text { um lava-jato }\end{array}$ & $\begin{array}{c}\text { Sou pedreiro, } \\
\text { mas } \\
\text { Estou sem } \\
\text { serviço. }\end{array}$ & $\begin{array}{c}\text { Trabalho com } \\
\text { meu tio em um } \\
\text { bar há um bom } \\
\text { tempo. }\end{array}$ & $\begin{array}{c}\text { Cuido de uma } \\
\text { criança e da casa } \\
\text { há dois anos. }\end{array}$ \\
\hline
\end{tabular}




\begin{tabular}{|c|c|c|c|c|c|}
\hline $\begin{array}{c}\text { (continuação) } \\
\text { 5) Quanto você } \\
\text { ganha em média? }\end{array}$ & $\begin{array}{l}\text { Depende, uns } \\
700 \text { reais }\end{array}$ & $\begin{array}{l}\text { Dividindo com } \\
\text { os colegas, } 30 \\
\text { reais por dia. }\end{array}$ & $\begin{array}{l}\text { Faço bico, } \\
\text { depende do } \\
\text { serviço, se for } \\
\text { empreitada. }\end{array}$ & $\begin{array}{c}\text { Ele me dá } 30 \text { reais } \\
\text { por semana. }\end{array}$ & $\begin{array}{c}\text { Um salário } \\
\text { mínimo mais vale } \\
\text { transporte }\end{array}$ \\
\hline $\begin{array}{l}\text { 6) Pega ônibus para } \\
\text { ir ao trabalho? }\end{array}$ & $\begin{array}{l}\text { Não, eu tenho } \\
\text { carro. }\end{array}$ & Não, vou a pé & $\begin{array}{l}\text { Depende do } \\
\text { lugar. }\end{array}$ & Sim. & Sim. \\
\hline $\begin{array}{l}\text { 7) Quanto tempo } \\
\text { gasta } \\
\text { no ônibus? }\end{array}$ & Nunca calculei. & Uns 7 minutos. & - & 10 minutos & $\begin{array}{l}40 \text { minutos mais } \\
\text { ou menos }\end{array}$ \\
\hline $\begin{array}{l}\text { 8) Qual a distância } \\
\text { do seu trabalho à sua } \\
\text { casa/escola? }\end{array}$ & $\begin{array}{c}\text { Dois } \\
\text { quilômetros }\end{array}$ & $\begin{array}{c}\text { Não sei. Só } \\
\text { umas duas } \\
\text { quadras }\end{array}$ & $\begin{array}{l}\text { Vai depender } \\
\text { de onde eu vou } \\
\text { trabalhar }\end{array}$ & $\begin{array}{l}\text { É no setor central, } \\
\text { dois quilômetros }\end{array}$ & 28 quilômetros \\
\hline $\begin{array}{l}\text { 9) Você trabalha } \\
\text { quantas horas por } \\
\text { dia? }\end{array}$ & Umas 9 horas & $\begin{array}{l}\text { De } 8 \text { horas às } \\
18 \text { horas }\end{array}$ & $\begin{array}{l}8 \text { horas, } \\
\text { quando } \\
\text { trabalho }\end{array}$ & $\begin{array}{l}\text { Trabalho só à } \\
\text { tarde na semana, e } \\
\text { à noite nos } \\
\text { sábados. }\end{array}$ & 8 horas. \\
\hline $\begin{array}{l}\text { 10) De que forma } \\
\text { você poderia } \\
\text { aumentar a sua } \\
\text { renda? }\end{array}$ & $\begin{array}{l}\text { Se eu tivesse } \\
\text { um ponto, } \\
\text { deixaria de } \\
\text { pagar aluguel }\end{array}$ & $\begin{array}{l}\text { Arrumando } \\
\text { outro } \\
\text { emprego, fixo. }\end{array}$ & $\begin{array}{c}\text { Tô estudando } \\
\text { pra isso. }\end{array}$ & $\begin{array}{l}\text { Arrumando um } \\
\text { emprego melhor. }\end{array}$ & $\begin{array}{c}\text { Eu não sei o que } \\
\text { fazer. }\end{array}$ \\
\hline $\begin{array}{l}\text { 11) Seu salário dar } \\
\text { para cobrir suas } \\
\text { despesas financeiras }\end{array}$ & $\begin{array}{c}\text { É difícil, mas, } \\
\text { minha esposa } \\
\text { me ajuda }\end{array}$ & $\begin{array}{c}\text { Dá pra eu me } \\
\text { virar }\end{array}$ & $\begin{array}{c}\text { Nem sempre, } \\
\text { tem semana } \\
\text { que sim, outra } \\
\text { não }\end{array}$ & $\begin{array}{c}\text { Não dá nem pra } \\
\text { mim, eu peço a } \\
\text { minha mãe. }\end{array}$ & $\begin{array}{l}\text { Não cobre, eu } \\
\text { ajudo o meu } \\
\text { marido. }\end{array}$ \\
\hline $\begin{array}{l}\text { 12) Contribui em } \\
\text { casa? }\end{array}$ & A maior parte & Sim, & Não. & Ajudo. & Cuido da casa. \\
\hline $\begin{array}{l}\text { 13) Quantos anos } \\
\text { você tem? }\end{array}$ & 33 anos & 38 anos & 17 anos & 25 anos & 57 anos \\
\hline
\end{tabular}




\begin{tabular}{|c|c|c|c|c|c|}
\hline $\begin{array}{l}\text { (continuação) } \\
\text { 14) Qual a finalidade } \\
\text { de ter voltado a } \\
\text { estudar? }\end{array}$ & $\begin{array}{l}\text { Deixar de ser } \\
\text { vendedor }\end{array}$ & $\begin{array}{c}\text { Recuperar o } \\
\text { tempo perdido } \\
\text { e mudar de } \\
\text { vida. }\end{array}$ & $\begin{array}{l}\text { Ter emprego } \\
\text { fixo. }\end{array}$ & $\begin{array}{l}\text { Não quero ser } \\
\text { chamada de burra }\end{array}$ & $\begin{array}{c}\text { Arrumar um } \\
\text { emprego que dê } \\
\text { pra eu ficar mais } \\
\text { tempo com meus } \\
\text { filhos }\end{array}$ \\
\hline $\begin{array}{l}\text { 15) Em sua opinião } \\
\text { para que serve o } \\
\text { estudo da Geografia? }\end{array}$ & $\begin{array}{l}\text { Estudar os } \\
\text { planetas? }\end{array}$ & $\begin{array}{l}\text { Conhecer } \\
\text { coisas. }\end{array}$ & $\begin{array}{l}\text { Estudar os } \\
\text { países. }\end{array}$ & Estudar a terra. & Muitas coisas \\
\hline $\begin{array}{l}\text { 16) De que forma } \\
\text { você estuda } \\
\text { geografia? }\end{array}$ & $\begin{array}{l}\text { Eu estudo para } \\
\text { a prova }\end{array}$ & $\begin{array}{l}\text { Presto atenção } \\
\text { no que a } \\
\text { professora diz. }\end{array}$ & Eu leio e gravo & Leio a apostilha. & Estudando. \\
\hline $\begin{array}{l}\text { 17) Quanto tempo } \\
\text { você tem para } \\
\text { estudar? }\end{array}$ & Só na escola & $\begin{array}{l}\text { Não tenho } \\
\text { tempo. }\end{array}$ & $\begin{array}{l}\text { À noite na } \\
\text { sala. }\end{array}$ & $\begin{array}{l}\text { Quando não tem } \\
\text { movimento no } \\
\text { bar. }\end{array}$ & $\begin{array}{l}\text { Não dá tenho que } \\
\text { lavar roupas. }\end{array}$ \\
\hline
\end{tabular}




\section{Dados do público pesquisado - Alunos da Educação de Jovens e Adultos Centro de Ensino Fundamental de $1^{\circ}$ Grau 10 do Gama.}

Amostra de 10 alunos do $2^{\circ}$ segmento

\begin{tabular}{|c|c|c|c|c|c|}
\hline $\begin{array}{l}\text { Perguntas/ } \\
\text { Entrevistados }\end{array}$ & 6 & 7 & 8 & 9 & 10 \\
\hline $\begin{array}{l}\text { 1) Escolaridade } \\
\text { necessária para as } \\
\text { atividades do seu } \\
\text { emprego? }\end{array}$ & $\begin{array}{c}\text { Não tenho } \\
\text { emprego. } \\
\text { Só tenho a } 5^{\text {a }} \\
\text { série. }\end{array}$ & $\begin{array}{l}\text { Não sei ao certo, } \\
\text { mas, preciso } \\
\text { estudar para } \\
\text { continuar no } \\
\text { emprego }\end{array}$ & $1^{\circ}$ grau? & $\begin{array}{l}\text { Perguntaram- } \\
\text { me se eu tinha o } \\
1^{\circ} \text { grau. }\end{array}$ & $5^{a}$ série. \\
\hline $\begin{array}{l}\text { 02) Você acha que a sua } \\
\text { experiência de vida } \\
\text { pode contribuir nas } \\
\text { aulas de geografia em } \\
\text { sala de aula? }\end{array}$ & $\begin{array}{l}\text { Todos podem } \\
\text { ajudar. }\end{array}$ & $\begin{array}{l}\text { Sim, contando } \\
\text { minhas estórias }\end{array}$ & Acho que sim. & $\begin{array}{l}\text { Agente tem } \\
\text { uma } \\
\text { experiência de } \\
\text { vida. }\end{array}$ & Não. \\
\hline $\begin{array}{l}\text { 03) Você costuma } \\
\text { utilizar o que você } \\
\text { aprende em geografia no } \\
\text { seu dia-a-dia? }\end{array}$ & $\begin{array}{c}\text { Eu entendo o } \\
\text { mundo }\end{array}$ & $\begin{array}{l}\text { Sim, vendo os } \\
\text { lugares. }\end{array}$ & $\begin{array}{l}\text { Faço cartaz no } \\
\text { mercado. }\end{array}$ & Não. & $\begin{array}{c}\text { Estou } \\
\text { estudando pra } \\
\text { isso. }\end{array}$ \\
\hline $\begin{array}{c}\text { 04) Qual é a sua } \\
\text { profissão? Quanto } \\
\text { tempo está empregado? }\end{array}$ & Sou do lar. & $\begin{array}{l}\text { Vigia há três } \\
\text { anos }\end{array}$ & $\begin{array}{l}\text { Sou cartazista. } \\
\text { Depende do } \\
\text { mercado. Estou } \\
\text { em dois a três } \\
\text { meses. }\end{array}$ & Sou padeiro & $\begin{array}{l}\text { Doméstica há } \\
\text { dois anos }\end{array}$ \\
\hline $\begin{array}{l}\text { 05) Quanto você ganha } \\
\text { em média? }\end{array}$ & $\begin{array}{c}\text { Só o que o } \\
\text { meu marido } \\
\text { me dar. }\end{array}$ & $\begin{array}{l}\text { Um salário e } \\
\text { meio }\end{array}$ & $\begin{array}{l}\text { Recebo por } \\
\text { semana. }\end{array}$ & 1.300 reais & 650 reais \\
\hline $\begin{array}{l}\text { 06) Pega ônibus para ir } \\
\text { ao trabalho? }\end{array}$ & Não. & Sim. & $\begin{array}{l}\text { Não, tenho } \\
\text { moto. }\end{array}$ & Tenho carro. & Sim. \\
\hline $\begin{array}{l}\text { 07) Quanto tempo } \\
\text { gasta no ônibus? }\end{array}$ & - & $\begin{array}{l}\text { Dá uns } 40 \\
\text { minutos }\end{array}$ & - & - & $\begin{array}{l}\text { Não sei, } \\
\text { acho que } \\
1 \text { hora }\end{array}$ \\
\hline
\end{tabular}




\begin{tabular}{|c|c|c|c|c|c|}
\hline $\begin{array}{c}\text { (continuação) } \\
\text { 08) Qual a distância } \\
\text { do seu trabalho à sua } \\
\text { casa/escola? }\end{array}$ & - & $\begin{array}{l}\text { Não sei, é no } \\
\text { Plano. }\end{array}$ & Não sei. & $\begin{array}{c}\text { É longe para } \\
\text { ir a pé. }\end{array}$ & Não sei. \\
\hline $\begin{array}{c}\text { (09) Você trabalha } \\
\text { quantas horas por } \\
\text { dia? }\end{array}$ & $\begin{array}{l}\text { Em casa o } \\
\text { tempo todo. }\end{array}$ & $\begin{array}{l}\text { Trabalho um } \\
\text { dia folga } \\
\text { outro, as vazes } \\
\text { trabalho à } \\
\text { noite. }\end{array}$ & 8 horas & $\begin{array}{c}\text { Acordo cedo, } \\
\text { trabalho } 8 \\
\text { horas }\end{array}$ & $\begin{array}{c}8 \text { horas na } \\
\text { semana e } 4 \\
\text { horas no } \\
\text { sábado }\end{array}$ \\
\hline $\begin{array}{l}\text { 10) De que forma você } \\
\text { poderia aumentar a } \\
\text { sua renda? }\end{array}$ & Não sei. & $\begin{array}{c}\text { Outro } \\
\text { emprego? }\end{array}$ & $\begin{array}{c}\text { Estudando } \\
\text { para } \\
\text { conseguir } \\
\text { outro } \\
\text { emprego. }\end{array}$ & $\begin{array}{c}\text { Trocando de } \\
\text { serviço }\end{array}$ & $\begin{array}{l}\text { Pedindo } \\
\text { aumento? }\end{array}$ \\
\hline $\begin{array}{l}\text { 11) Seu salário dar } \\
\text { para cobrir suas } \\
\text { despesas financeiras? }\end{array}$ & $\begin{array}{l}\text { Não tenho } \\
\text { salário. }\end{array}$ & Dá pra viver. & $\begin{array}{l}\text { Mai s ou } \\
\text { menos }\end{array}$ & $\begin{array}{l}\text { O salário } \\
\text { sempre é } \\
\text { pouco. }\end{array}$ & $\begin{array}{l}\text { Não pago } \\
\text { aluguel com } \\
\text { meu marido }\end{array}$ \\
\hline $\begin{array}{l}\text { 12) Contribui em } \\
\text { casa? }\end{array}$ & Não. & Vivemos dele. & Sim. & $\begin{array}{c}\text { Sustento } \\
\text { minha } \\
\text { família. }\end{array}$ & Sim. \\
\hline $\begin{array}{c}\text { 13) Quantos anos você } \\
\text { tem? }\end{array}$ & 57 anos & 34 anos & 22 anos & 47 anos. & 23 anos. \\
\hline $\begin{array}{l}\text { 14) Qual a finalidade } \\
\text { de ter voltado a } \\
\text { estudar? }\end{array}$ & $\begin{array}{l}\text { Não quero } \\
\text { ficar só em } \\
\text { casa. }\end{array}$ & $\begin{array}{c}\text { Todos tem } \\
\text { mais estudo } \\
\text { que eu no meu } \\
\text { serviço. }\end{array}$ & $\begin{array}{c}\text { Terminar o } 2^{\circ} \\
\text { grau. }\end{array}$ & $\begin{array}{l}\text { Melhorar a } \\
\text { vida }\end{array}$ & $\begin{array}{l}\text { Melhorar de } \\
\text { vida. }\end{array}$ \\
\hline $\begin{array}{l}\text { 15) Em sua opinião } \\
\text { para que serve o } \\
\text { estudo da Geografia? }\end{array}$ & Ler apostila. & $\begin{array}{l}\text { Estudar o } \\
\text { Brasil? }\end{array}$ & $\begin{array}{l}\text { Conhecer o } \\
\text { nosso país. }\end{array}$ & $\begin{array}{l}\text { Tem que } \\
\text { estudar de } \\
\text { tudo }\end{array}$ & $\begin{array}{l}\text { Passar de } \\
\text { ano. }\end{array}$ \\
\hline $\begin{array}{l}\text { (Continuação) } \\
\text { Perguntas/ } \\
\text { Entrevistados }\end{array}$ & 6 & 7 & 8 & 9 & 10 \\
\hline
\end{tabular}




\begin{tabular}{|c|c|c|c|c|c|}
\hline $\begin{array}{c}\text { (continuação) } \\
\text { 16) De que forma você } \\
\text { estuda geografia? }\end{array}$ & Copio e leio. & $\begin{array}{c}\text { Escuto a } \\
\text { professora. }\end{array}$ & $\begin{array}{c}\text { Eu leio e } \\
\text { entendo }\end{array}$ & $\begin{array}{c}\text { Assisto às } \\
\text { aulas. }\end{array}$ & Decoro \\
\hline $\begin{array}{c}\text { 17)Quanto tempo você } \\
\text { tem para estudar? }\end{array}$ & $\begin{array}{c}\text { Depois que } \\
\text { termino de } \\
\text { arrumar as } \\
\text { coisas }\end{array}$ & $\begin{array}{c}\text { Estou cansado, } \\
\text { é difícil. }\end{array}$ & À noite & Não tenho & Pouco tempo \\
\hline
\end{tabular}

\title{
4 - Justificativa e caracterização do problema
}

Ao longo dos anos, através das conversas informais com os professores da Rede Pública de Ensino, verificou-se que o ensino de Geografia na Educação de Jovens e Adultos, vem sendo trabalhado de forma precária e homogênea com o ensino regular. Deixando de se atentar as especificidades e disfunções presentes nesta modalidade de ensino. Quanto a isso, ressalta-se a inobservância por parte do professor a cerca do ritmo de vida dos alunos, condicionado a sua situação sócio-econômica. Muitos desses alunos possuem uma realidade concreta, uma carga horária de trabalho igual ou superior a 8 horas diárias. Local de moradia longe de casa e da escola e baixos salários (ver anexos). Fatores estes que queiram ou não, podem interferir no processo de ensino aprendizagem.

Segundo Carneiro (2002):

\begin{abstract}
"O aluno trabalhador, após enfrentar uma jornada média de oito horas trabalho, desloca-se rumo à escola e deposita nela a esperança de poder mudar de vida; também enxerga na escola a possibilidade de aliviar o fardo pesado de trabalho que tem de enfrentar nos cinco dias da semana (quando não seis). Isto sem contar o tempo gasto para deslocar-se de sua casa ao trabalho, do trabalho à escola e, no fim do dia, da escola à sua casa."
\end{abstract}

É também, de se notar um desgaste físico e psicológico deste público trabalhador no decorrer do dia (de casa para o trabalho e escola) contribuindo para uma queda no desempenho escolar e principalmente na sua motivação com o passar do tempo, em relação aos conteúdos trabalhados e a metodologia empregada.

Mafra (1989, p.38) relata:

"Desnuda-se, pois diante de nós um fato social concreto. Metade do alunado na escola média brasileira é hoje constituída de estudantes trabalhadores 
que se esforçam e se desgastam física e mentalmente na luta para estudar e trabalhar sob as condições postas pela vida fora da escola e pelo cotidiano escolar. No deslocar-se da rotina diária entre o trabalho e a escola, muitos desistem, enquanto outros rompendo barreiras conseguem alcançar o término desse nível de escolarização."

A falta de abordagens metodológicas que por conta de si mesmas reconheçam as diferenças existentes entre uma criança e um adulto pode fazer com que o ensino desta disciplina se processe dentro das duas modalidades de ensino (diurna e noturna) de forma única. Se pegarmos os conteúdos de Geografia proposto pela Secretaria de Educação do DF para a Educação de Jovens e Adultos e Ensino Regular, observaremos que eles são os mesmos trabalhados para as duas modalidades de ensino e que apesar da sua importância, frente ao mercado de trabalho e à vida acadêmica do aluno, precisam desvincular-se de métodos que, segundo entrevista com os alunos, sugerem a absorção de conteúdos por processo de memorização, devendo ao contrário, virem acompanhados de significados para ambos os públicos. Para Ramos (2005, p.107),

\footnotetext{
"apreender o sentido dos conteúdos de ensino implica reconhecê-los como conhecimentos construídos historicamente e que se constituem, para o trabalhador, em pressupostos a partir dos quais se podem construir novos conhecimentos no processo de investigação e compreensão do real."
}

As observações e entrevistas feitas em sala de aula sugerem que as metodologias aplicadas na Educação de Jovens e Adultos para as aulas de Geografia no Centro de Ensino 10 do Gama, são as mesmas oferecidas ao ensino regular entre alunos de 10 e 14 anos com o fator tempo reduzido, aparentemente não se leva em consideração os sujeitos a serem trabalhados, passando os conteúdos a serem dissociados da realidade do aluno da EJA. Existindo assim, dentro da Secretaria de Educação do DF, a lei do menor esforço, onde grande parte dos professores admitem que o conteúdo de Geografia esteja fora da realidade do aluno noturno, levando-os a questionarem se o que é dado vai ser usado no dia-a-dia, em casa ou no emprego. Além do mais, diferenças de aspectos financeiros, temporais, psicológicos e perspectivos são desprezados.

M. Knowles (1971) informa que:

"Em situações de aprendizagem os adultos diferenciam-se de crianças e jovens, principalmente em relação ao autoconhecimento - a criança e o jovem percebem-se mais dependentes do professor, enquanto os adultos se consideram responsáveis pelo próprio processo de aprendizagem; experiência - adultos trazem experiência de vida acumulada, o que pode servir como fonte comum, sendo cada integrante um novo recurso de 
aprendizagem para outros; prontidão - crianças e jovens precisam atingir certo nível de amadurecimento físico e psíquico para aprenderem determinados comportamentos e/ou conhecimentos. Os adultos também desenvolvem maturidade em áreas diferenciadas, porém de cunho social, levando-os a desenvolver interesses específicos e aprender formas mais complexas de conduta em termos de papéis sociais; perspectiva temporal as crianças e jovens aprendem para o futuro, enquanto o adulto para a aplicação imediata; orientação da aprendizagem - crianças e jovens aprendem assuntos constantes em um currículo que serve de base de conhecimentos para a vida profissional e social, enquanto os adultos procuram aprender aquilo que possa contribuir para resolver os problemas que enfrentam no presente, aquilo que carecem para melhorar seu desempenho e enfrentar os desafios que surgem no dia-a-dia."

Logo, a necessidade deste trabalho, surgiu da falta de adequabilidade dos conteúdos de Geografia à realidade e especificidades dos alunos da Educação de Jovens e Adultos, bem como de abordagens metodológicas diferenciadas a serem trabalhadas dentro e fora da sala de aula, buscando assim, fazer com que os conteúdos passem a ser dotados de significados para o aluno do noturno. Pois apesar de verem a escolarização como um meio de alcançar a promoção, esses alunos em sala de aula, não estabelecem nenhuma relação dos conteúdos de Geografia e o seu mundo de trabalho.

Segundo LACOSTE (1977 p.38):

"Geografia é a única disciplina que surge como um saber sem a mínima aplicação prática fora do sistema de ensino."

Nota-se, então, que as respostas dos alunos segundo entrevistas, com relação aos conteúdos de Geografia previstos no currículo escolar da Educação de Jovens e Adultos, numa perspectiva da prática educativa que vivenciam, estão muito longe das suas necessidades práticas de vida, em especial às ligadas ao trabalho. Sendo assim, necessário se faz, trabalham o conteúdo já existente, de uma forma mais contextualizada com o aluno. Tarefa, uma das mais complexas, tendo em vista que os professores de Geografia que atuam no ensino noturno, alegam não terem recebido nenhuma formação ou capacitação para trabalharem com essa modalidade de ensino.

Para Carvalho (1994, p.15):

"Sem o diálogo entre o trabalhador e o conteúdo de aprendizagem, sem o diálogo entre a prática profissional e a prática escolar, não haverá possibilidade de que o conhecimento adquirido através do cotidiano profissional seja reelaborado a partir da prática escolar. Sem esse diálogo, dificilmente se conseguirá que o trabalhador conheça os meios de superação de sua condição social e os limites e possibilidades que the são impostos pela sociedade mais ampla". 
Os conteúdos de Geografia por muitos professores acharem extensos e não haver tempo para trabalhá-los, durante o calendário escolar, faz com que haja uma defasagem durante o semestre, não sendo atingido integralmente, obrigando o professor a gastar mais tempo em sala de aula na sua seleção, dentro do conteúdo geral, buscando assim, levar em conta os itens que serão pré-requisitos para as unidades posteriores. Sendo preciso, assim, estabelecer que aspectos dos conteúdos, devem ser valorizados em função da capacidade e interesse dos alunos, das experiências a serem trabalhadas, das necessidades dos grupos aos quais pertencem da estrutura sócio-econômica da comunidade do Centro de Ensino 10 do Gama, do tempo e das condições materiais disponíveis na escola. Trabalhar conteúdos de Geografia com temas atuais que façam parte da sua vivência, tendo em mente todos os problemas enfrentados pelos alunos, na possibilidade de lhes dá uma abordagem metodológica prática e condizente com a sua realidade social.

\section{5 - Objetivos}

\section{Geral:}

Discutir a adequação dos conteúdos de Geografia utilizados na Educação de Jovens e Adultos do Centro de Ensino 10 do Gama à realidade sócio-cultural dos mesmos, através de novas abordagens metodológicas e formas diferenciadas de aplicação, discussão e assimilação dos mesmos.

\section{Específico:}

-Despertar nos alunos da EJA o interesse em estudar Geografia, visualizando-a não apenas como uma disciplina descritiva e de memorização, mas como suporte de conhecimento, investigação, associação e motivação na resolução dos problemas do seu cotidiano.

-Tornar a discussão dos conteúdos de Geografia mais fácil, e prazerosa, através de associações às experiências pessoais dos alunos.

-Fomentar a criação de metodologias e técnicas que motivem a aprendizagem do ensino de Geografia.

- Instigar os professores de Geografia e demais professores a se atentarem acerca das especificidades de ordem culturais, físicas, temporais e motivacionais que interferem na Educação de Jovens e Adultos. 
-Contribui com os alunos da Educação de Jovens e Adultos para superação das dificuldades encontradas em associar os conteúdos de geografia à realidade social de cada um.

\section{6 - Atividades / Responsabilidades}

Inicialmente foi feito uma pesquisa na Secretaria do Centro de Ensino 10 do Gama com a colaboração do Secretário Escolar, de onde foram coletadas informações dos alunos - turmas envolvidas - através dos formulários de matrícula (SOMA/FIAT). Também foram feitas duas observações em sala de aula com a autorização do professor; elaborados questionários distribuídos a alunos e professores para posterior, análise e diagnóstico. Em seguida foi feito um levantamento junto à Coordenação Pedagógica acerca dos conteúdos de geografia ministrados nas turmas da EJA, seus objetivos e carga horária. A partir daí, verificou-se que na escola à noite, a Geografia é trabalhada no $2^{\circ}$ segmento, referente às $5^{\mathrm{a}}, 6^{\mathrm{a}}, 7^{\mathrm{a}}$ e $8^{\mathrm{a}}$ séries do Ensino Fundamental , possuindo a duração de 1.600 (um mil) e seiscentas horas, distribuídas em 4 (quatro) semestres de 400 (quatrocentas) horas cada um, equivale a antiga Fase III do Ensino Supletivo, desenvolvido de forma presencial, com uma jornada diária de 4 (quatro) horas por turma ( Proposta de Educação de Jovens e Adultos - SEEDF-2005). Cada série é composta por uma quantidade de conteúdos trabalhados semestralmente e distribuídos em uma carga horária de 60 horas para esta disciplina.

Os objetivos e os conteúdos de Geografia estão organizados no Currículo Básico de Educação das Escolas Públicas do Distrito Federal de onde os professores, segundo a Proposta de Educação de Jovens e Adultos (2004 p.12), "ficarão responsáveis pelas adaptações metodológicas necessárias ao atendimento das especificidades da clientela". Em seu objetivo geral os conteúdos visam permitir ao aluno analisar e interpretar o espaço natural econômico e social, bem como concebê-lo criticamente, na busca de sua transformação. Em seus objetivos específicos:

- Proporcionar ao educando a capacidade de entender a relação entre a dinâmica social e a produção do espaço Geográfico, visando ao desenvolvimento de sua consciência crítica, reflexiva e criadora.

- Proporcionar ao aluno a compreensão do espaço periférico em função dos interesses das potencias econômicas mundiais.

- Compreender a nova ordem internacional iniciada após a guerra fria, buscando dar ao aluno uma visão realista do mundo desenvolvido a partir das mudanças econômicas e geopolíticas atuais. 
Quanto aos conteúdos seguem no quadro abaixo, os que são utilizados para a $6^{\mathrm{a}}$ série, $2^{\circ}$ Segmento a título de exemplificação:

\section{Conteúdo Programático de Geografia}

- Noções de Espaço Brasileiro

- O Brasil e a Divisão Internacional do Trabalho

- Brasil - país subdesenvolvido industrializado

- Desigualdades sociais a dependência econômica

- Organização Regional do Brasil

- Conceito de região

- A natureza como critério de regionalização

.. domínios morfoclimáticos do Brasil

- A ocupação do espaço e a organização regional

.. a formação histórico-econômica e a configuração das regiões brasileira

.. a divisão oficial do IBGE

.. as regiões geoeconômicas

- Órgãos de planejamento regionais

- Questões separatistas.

- Produção do Espaço Brasileiro

- As relações entre os elementos naturais e humanos através do trabalho e suas conseqüências.

.. agropecuária e atividade extrativas vegetai e animal

... relevo

... solo

... clima

... hidrografia

... vegetação

... estrutura fundiária

... transformação na agricultura

... as relações de trabalho

... indústria

... extrativismo mineral

... energia

... as migrações no Brasil

... mercado de trabalho-economia informal

... o fluxo das riquezas

... comércio

... transporte

... comunicações

- A população brasileira

... composição da população brasileira

... crescimento da população brasileira

... distribuição da população brasileira

... população rural e urbana

... urbanização

Fonte: Proposta Pedagógica de Educação de Jovens e Adultos 2005/ SEEDF. 
Segundo a Coordenação Pedagógica e o grupo de professores de Geografia, (fundamentais no levantamento dos dados), que atuam nos dois turnos: diurno e noturno, os conteúdos citados, são os mesmos utilizados para as duas modalidades de ensino Regular e Educação de Jovens e Adultos, não sendo completamente atingidos em função das disfunções existentes dentro da modalidade. O que leva a refletir se os mesmos estão sendo utilizados como fins não como meios.

Através dos questionários aplicados aos alunos e professores foi possível detectar as maiores disfunções incidentes na escola noturna.

Disfunções encontradas no Centro de Ensino 10 do Gama- Noturno.

Carência de professores

- Abordagem metodológica inadequada ao aluno.

- Falta de servidores na faxina, no lanche e na secretaria.

- Violência na escola.

- Falta de Apoio Didático.

- Conteúdos extensos, impossíveis de serem vistos em função do tempo, poucas semanas

- Biblioteca fechada para consultas.

- Livros de Geografia desatualizados.

- Falta de cursos de formação e capacitação para professores (para lidar com a educação de adultos).

- Falta de respeito com o ritmo do aluno.

Mesmo que se reconheça conforme visto acima que há diferenças entre o aluno do noturno e do diurno, nota-se que os professores do Centro de Ensino 10 do Gama, trabalham de maneira uniforme. Elaborando quando sim, o mesmo plano de aula para as duas realidades, registrando no diário os mesmos assuntos e avaliam da mesma forma.

Há uma preocupação em se dá todo o conteúdo de geografia, tendo-os como fim, quando o importante é assimilar o fundamental, vendo-os como meios de se desenvolver modos de sentir, pensar e fazer. E não transmiti-los diretamente, mantendo os alunos passivos, sem tempo de explorá-los. 
LIBÂNEO (1986) coloca que:

"o importante não é a transmissão de conteúdos específicos sistematizados, mas despertar uma nova forma da relação com a experiência vivida“.

GADOTTI, (1987) coloca que:

"O aluno perde o interesse diante de disciplinas que nada têm a ver com a sua vida, com suas preocupações. Decora muitas vezes aquilo que precisa saber de forma forçada para prestar exames e concursos. Passando as provas, tudo cai no esquecimento."

A falha mais grave encontrada entre os professores de Geografia não é o fato de priorizarem o aspecto quantitativo dos conteúdos e sim de desprezarem o ser histórico do aluno, essa Geografia trabalha de forma tradicional, marginalizando o próprio aluno, sujeito do processo de conhecimento e o transforma em objeto deste processo.

Segundo fragmentos de um texto - Projeto Saber da Terra, MEC/ Ministério do Trabalho Emprego e Desenvolvimento Agrário retirado do portal EAD:

"Uma das principais falhas que pode comprometer o processo de aprendizagem de um aluno é ignorar o contexto que ele vive, suas características e necessidades próprias."

Os alunos chegam à escola com um saber peculiar sobre o espaço, resultado de sua experiência imediata de vida, com uma consciência própria a que (Spier. 1986) denomina "Espaço Real". E, nós professores, devemos, então, ensinarmos o espaço Geográfico, aqueles dados espaciais que eles não têm, sobre um espaço que eles nunca experimentaram, nem conhecem. Para Moyses (1995 p.36), o professor deve assumir o papel de mediador entre o saber e prática para que esse saber seja:

"Socialmente sistematizado ou saber científico e o saber do próprio aluno,... deve-se partir do conhecimento que o aluno já possui, de seus gestos e sua cultura e ajudá-los a ir mais longe, até a cultura elaborada."

Diante disso, segue abaixo sugestões alternativas para se abordar os conteúdos de Geografia em sala de aula, nas etapas de $5^{\mathrm{a}}$ e $8^{\mathrm{a}}$ séries do Centro de Ensino 10 do Gama. 
Conteúdo: População

Para trabalhar com o tema: população, crescimento populacional, população urbana, pede-se aos alunos da Educação de jovens e alunos que reúnam dados próximos a sua realidade, tais como informações a respeito da família, número de pessoas, sexo e idade de cada membro da família. De posse dos dados, agruparemos a turma em três gerações diferentes, dos mais jovens aos mais velhos em cada família, quantos são do sexo feminino, quantas estão grávidas, se há recém-nascidos, se foi de parto cesariano ou normal. Quantas pessoas estudam, trabalham e contribuem com a renda familiar.

De posse dos dados sobre idade e sexo, pediremos aos alunos para construir uma pirâmide que permitirá também, diagnosticar a tendência do crescimento populacional da amostra. Quanto maior a base, maior será a tendência para o crescimento populacional, pois teremos mais indivíduos na faixa reprodutiva. Diante disso, discutiremos com os alunos, quais as implicações de se ter uma família com um maior número de pessoas, onde poucos contribuem com a renda familiar. Se, em função disso, os recursos financeiros tornam-se escassos e se há uma interferência na qualidade de vida dos mesmos.

Atividades complementares podem ajudar nesta atividade, conforme o local de trabalho e disponibilidade de tempo de cada aluno, como visitas aos hospitais nos dando aproximadamente o número de crianças que nascem por dia.

Trabalhar também, os deslocamentos populacionais, tendo em vista serem, os alunos em sua maioria, oriundo do nordeste, região que enfrenta problemas climáticos como a seca do semi-árido e que expulsa centenas de pessoas as áreas urbanizadas.

Discutir questões como cidadania e sustentabilidade; respeito às diferenças culturais entre nordestinos, candangos e demais regiões. Políticas capitalistas que acabaram expulsando milhares de nordestinos de suas terras. Como o Agro-negócio, levando-os ao subemprego (camelôs, diaristas) em outras regiões, a prostituição, a exclusão social e a degradação ambiental. Levá-los a refletirem sobre a necessidade de reivindicar políticas públicas de acesso à água, a habitação e a terra para os alunos agricultores.

Trabalhando assim, em sala, valores como o respeito ao ser humano, ao regionalismo e a sua cultura. ( $7^{\circ}$ Encontro Nacional de Articulação no Seminário Brasileiro - RADIS n 94 - junho de 2010).

\section{Conteúdo: Globalização}

Pede-se aos alunos que pesquisem palavras em outras línguas (estrangeirismo que dificulta a comunicação em nosso país, como o uso indiscriminado da língua inglesa e a sua valorização, ou qualquer outra que causa constrangimento a quem não domina. Exemplo: é o Banco do Brasil que é uma instituição brasileira e usa palavras estrangeiras como 
Personal Banking. Podem pesquisar em casa em revistas, jornais, televisão, estabelecimentos comerciais e shopping Center. Outro exemplo são as palavras que são usadas na informática e que precisam ser traduzidas para tornar acessível essa atividade aos alunos. Discutir com os alunos sobre a influência da mídia na formação familiar. Como a televisão age propagando modelos. Exemplo de um texto tomado de uma revista "feminina"

"Aqui está o que fazem nove dentre dez esposos nacionais, nos dias de hoje, quando voltam para casa (rostos em geral pálidos, olhos cansados) depois de sua jornada normal de oito oras de trabalho, tiram as sandálias, , atiram-se no sofá favorito e assistem televisão" (Revista Escola 2010)

Discutiremos com os alunos acerca do lançamento no mercado de produto culturais de um nível de qualidade deplorável e destinados as classes populares: fotonovelas, discos, cantores, e programas de televisão. Ainda que massiçamente consumidos por muitos de nossos alunos, não são culturas populares, porque não são criações do povo e sim dos setores dominantes, aumentando assim a alienação do povo. ( Uma Escola para o povo) Maria Tereza Nidelcoft $14^{\mathrm{a}}$ Edição - Editora Brasiliense). Sugere-se também, pedir aos alunos mais velhos que tragam um rádio para a escola para verificar através das diversas freqüências (FM), quantas músicas são estrangeiras e quantas são brasileiras. Faremos uma observação na turma identificando através de roupas e objetos pessoais presentes, (camisetas, bonés, tênis) quantos são produtos estrangeiros, quantos são produzidos no nosso pais e se isso, não é um reflexo da perda de uma identidade cultural.

\section{Conteúdo: América Latina}

Para trabalhar este assunto o professor pode valer-se de uma série de recursos. Por exemplo, solicitar aos alunos que elaborem poesias e paródias com fotografias, peças teatrais, cantigas de cordel, enfatizando a cultura, língua e costumes do território (nordeste e demais regiões). Bem como aproveitar músicas que ressaltem em seu conteúdo a matéria, utilizando-se da letra escrita onde os alunos retiraram trechos e identificaram os diferentes traços culturais e regionais presentes nas mesmas. Analisar também a colonização da América Latina, em especial, do Brasil, e as políticas de dominação inseridas nos aparelhos ideológicos do Estado (Igreja, Escola). Discutir a colonização brasileira e suas facetas. O acesso e as oportunidades à educação antes e hoje dos povos mestiços, indígenas e quilombolas, conforme exemplo abaixo:

"O combate a desigualdade étnico-racial do Governo Federal - reservando bolsas para os cidadão auto declarados negros, pardos ou índio em relação 
ao analfabetismo funcional - adultos com menos de quatro anos de estudo cerca de $26 \%$ do brancos se enquadram nessa categoria contra $47 \%$ dos afro-descendentes" (Secretaria de Educação Continuada, Alfabetização e Diversidade - SECAD/ME/EAD)

Como os povos (indígenas) foram e continuam sendo vistos. O que a mídia prega sobre o mesmo, analisando a contribuição dos alunos descendentes de povos indígenas e quilombola, suas histórias, contos e experiências. Desmascarando a ideia de que o índio era um ser terrível, perigoso e preguiçoso. Mostrando que o mesmo hoje, junto com outros povos (descendentes de quilombolas) continuam sendo subjugados, vencidos tendo suas terras tomadas.

Segundo dados do IBGE:

Eles são 734 mil espalhados por todo o país, no entanto, durante muito tempo, os indígenas foram obrigados a conviver com uma política de Estado repressiva que os priva de uma série de direitos. Eram considerados incapazes e para conquistar sua cidadania, sua cidadania tinha que passa por um processo em que sua cultura era praticamente aniquilada, diluindo totalmente sua identidade.(Uma cultura com diversas faces - SECAD/EAD).

Conteúdo: Conflitos Étnicos no Mundo

Aqui, trabalha-se com os conflitos no Oriente Médio - Palestinos e Judeus, no continente Africano - Guerra Civil em Ruanda e demais estados. Em seguida faz-se uma discussão sobre o tema violência, solicitando aos alunos da Eja que dêem sugestões sobre as várias formas de violência que presenciamos no dia-a-dia, na escola, no trabalho e na sociedade de um modo geral. Paralelo a essas atividades pode-se discutir textos que ressaltem os direitos e deveres do cidadão no convívio social, bem como a Declaração Universal dos Direitos Humanos, a Constituição e os direitos e deveres do Aluno trabalhador ( direito a educação, saúde, segurança, habitação, lazer e a vida).O Código do Consumidor, O Estatuto da Criança e do Adolescente, o Estatuto do Idoso e a LDB. Elaborar palestras com outras instituições que trabalham com programas sociais. A Escola Aberta, lançada em outubro de 2004, oferecem nas escolas públicas, aos fins de semana, uma série de Oficinas para os membro das comunidades, abordando temas como Direitos Humanos, cidadania e meio ambiente. SECAD em parceria com a SEB/MEC/FNDE e UNESCO.

Estes temas podem ser trabalhados através do círculo de culturas; método Paulo Freire, em que consiste em escolher uma palavra geradora subtraída do universo vivencial 
dos alunos. A partir da problematização desta palavra estaremos fazendo discussões acerca do tema, levantando questões referentes ao universo social dos alunos. e pedindo que os mesmos elaborem cartazes e painéis sobre o assunto. Utiliza-se de vídeo, e da televisão na exploração de notícias importantes mostradas nos jornais.

Conteúdo: Região Natural

Numa visão crítica dos conceitos de região natural e Geográfica trabalha-se com os alunos da Eja as desigualdades existentes em cada região, já que há uma heterogeneidade muito grande, quanto ao lugar de origem dos mesmos, sendo maioria proveniente do nordeste. Discutindo com cada aluno o que eles sabem de sua cidade, estado e especificidades de sua região, sua cultura e riqueza regional. Identificando na turma os sotaques regionais contribuições na culinária, vestimenta e música, fácil de ser explorada em feiras culturais,gincanas, sarais, oficinas e paródias, promovidas pelos alunos e demais membros da comunidade escolar.

\section{Conteúdo: Espaço Urbano}

Quanto à urbanização, pode-se trabalhar com os alunos as transformações existentes na quadra, no seu bairro e cidade ( construção de escolas, hospitais, comércio, praças e residências) fazendo analogias temporais de como era a cidade há dez anos atrás, quando ele chegou e hoje. Se houve o aumentou da população de sua cidade, os problemas sociais (violência e desemprego), identificando os agentes que provocaram essas mudanças e qual o seu papel nessa transformação. Visualizar o crescimento de sua cidade a partir de exercícios, tais como: dependendo da estrutura da sua cidade, elaboração de desenhos das ruas, se o traçado influencia no gasto de combustível, se há muitos quebra-molas, gastos com combustível, com segurança, escoamento de água, bueiros, umidade se for próximo aos rios ou enchentes.

Fazendo um exercício de visualização no percurso de seu trabalho até a escola e, da escola até em casa. Ao se trabalhar com as cidades, deve levar o aluno a entender que muitas cidades surgiram de movimentos populares, alguns até bem próximos deles, como os acampamentos e assentamentos: Paranoá e Núcleo Bandeirante, Santa Maria e Recanto das Emas, identificando se possível nas turmas ou nas famílias dos alunos, imigrantes que contribuíram na formação destes espaços. Pedir aos alunos que tragam de casa fotografias, antigas e atuais, cartões postais e reportagens sobre diversos lugares comparando-os. Deve-se questionar junto aos alunos da Eja porque o estado nunca quis resolver o problema habitacional; mas sim, utilizá-los como objeto de manipulação política econômica e ideológica. Neste caso, discussões sobre temas: Eleição, Habitação e saneamento básico são importantes. 
Conteúdo: Hidrografia

O rio tem um significado diferente para os alunos, principalmente aqueles trabalhadores do campo ou da cidade. Ele será aquele que vai permitir a plantação, o fornecimento de água para beber, a lavagem de roupa, a sua alimentação (pescaria), energia elétrica e em muitos casos, meios de transporte, fundamentais para a sua sobrevivência e de sua família. Assume também, importância vital para as sociedades humanas à medida que a água passa não só apenas assumir um valor no mercado, mas também na sobrevivência das espécies. Neste caso pede-se aos alunos da EJA que façam comparações entre os valores pagos pela conta de água e o consumo da mesma no dia-adia. Levando-os a se atentarem contra o desperdício, consumo exagerado e poluição da mesma. Exercícios práticos podem ser solicitados, como não deixarem torneiras pingando, nem abrirem exageradamente, utilizarem a água do tanque depois da lavagem de roupa, para molharem as calçadas. Levantar juntos aos alunos da Eja, questionamentos como a quem pertence a água. Se ela é sinônimo de poder. Se há quantidade e qualidade suficiente para todos. Se na sua quadra tem água encanada, caixa d'água, ou se falta água. Para os alunos da Educação de Jovens e Adultos que moram no campo, chácaras, se as localizações dos poços e lagos são em áreas privadas, se há cercas ou barreiras.

\section{Conteúdo: Clima}

Ao se trabalhar com este conteúdo pode se pedir aos alunos da Eja um levantamento sobre a influência do mesmo na sua vida e da população de sua cidade. De que forma o clima interfere no dia-a-dia do aluno. Se nos dias quentes a turma está com roupas leves, nos dias frios, agasalhos, se a alimentação de cada aluno varia conforme o tempo, comidas leves ou pesadas ou seja, como o clima e o tempo influenciam na cultura, nos costumes dos alunos (forma de se vestir de se alimentar). Se os alunos conseguem identificar na sua casa, rua ou cidade pessoas afetadas pela interferência climática (doenças respiratórias, alergias etc.). Pode-se sugerir aos alunos trabalhos complementares, como visitas aos hospitais para pesquisas estatísticas sobre o números de pessoas doentes - alérgicas ou com problemas respiratórios. Visitas ao DNMET- Departamento Nacional de Meteorologia. A influência do clima também pode ser trabalhada com os alunos a partir de visitas pelos mesmos à farmácias e hospitais para saberem que tipos de doenças são mais comuns no tempo seco ou mudança climáticas. Exemplo no DF o período de seca produz um terrível efeito sinérgico com baixa umidade relativa do ar e alta concentração de poeira em suspensão, lotando os hospitais, com crianças e idosos com problemas respiratórios. Diante disso, podemos discutir com os alunos da Eja, possíveis soluções. 


\section{7 - Cronograma}

11/04 - Visita à Secretaria do Centro de Ensino 10 do Gama para levantamento de documentos - Ficha Soma - Ficha Fiat - referente a caracterização do público a ser atendido.

16/04 - Consulta na Secretaria da Escola ao SGE - Sistema de Gestão Escolar (para levantamento de dados - EJA)

20/04 - Aplicação de questionário em sala de aula, complementar a coleta de dados retirados da Secretaria da Escola.

30/04 - Análise dos dados coletados na Secretaria da Escola (fichas Soma/Fiat)

03/05 - Levantamento junto a direção da Escola - (espaço físico e recursos humanos)

08/05 - Análise dos dados coletados junto a direção da Escola.

20/04 - Pesquisa Bibliográfica.

09/05 - Conversa com os demais professores de Geografia do Centro de Ensino 10 do Gama.

01/08 - Aplicabilidade do projeto

11/11 - Avaliação dos resultados do projeto.

\section{8 - Parceiros}

Apoio Pedagógico: José Barros

Coordenadora de Geografia: Lídia m.

Assistente Administrativo- Luciano - Ciências

Secretário Escolar - Zenildo

Alunos, Comunidade Escolar, EAP, DRE, SESI, SENAI, ONGS outras instituições de caráter governamental. 


\section{9 - Orçamento}

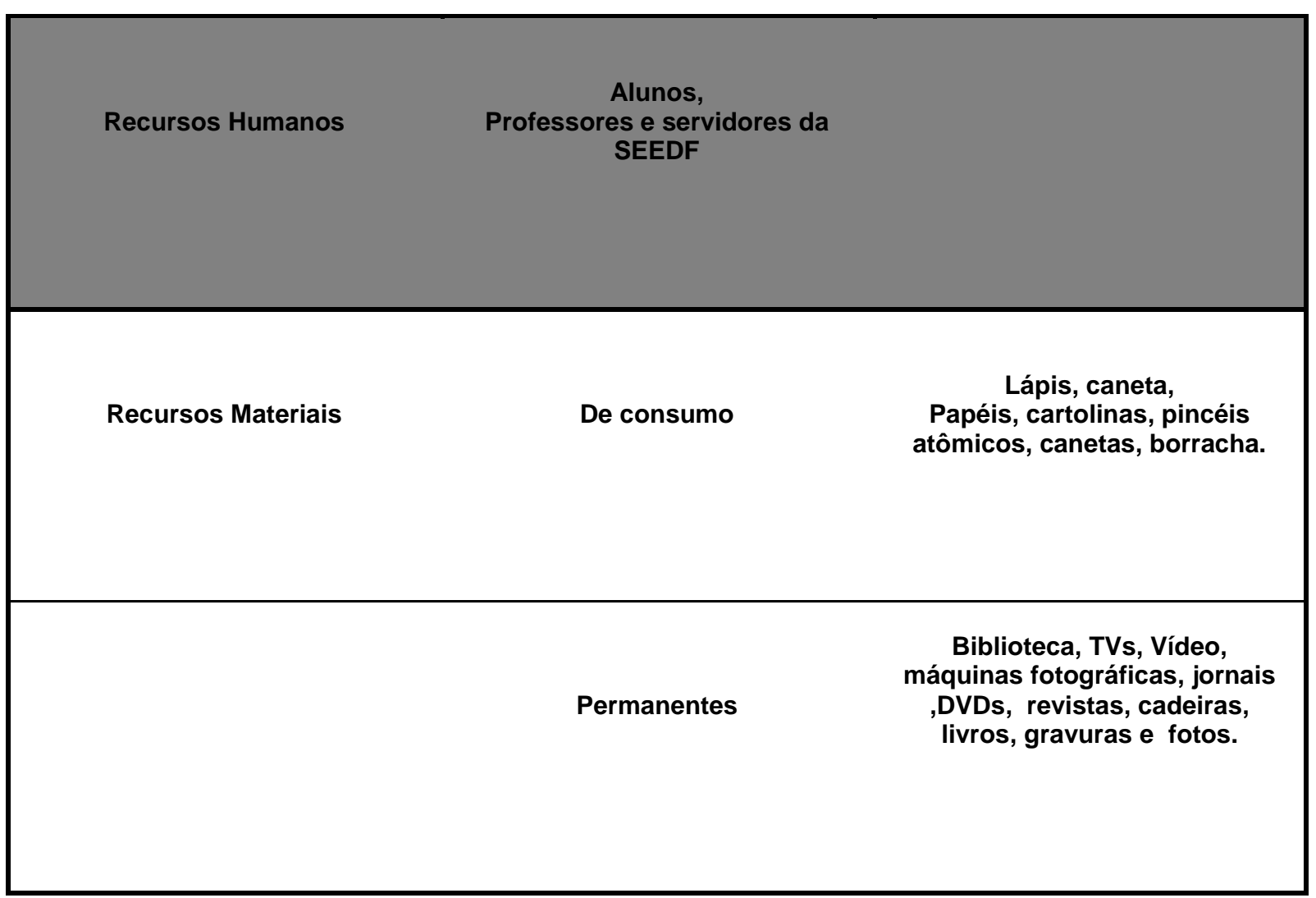

\section{0 - Acompanhamento e avaliação}

O acompanhamento e a avaliação do projeto serão feitos ao longo do processo com a participação da Coordenação pedagógica, e da comunidade escolar do Centro de Ensino 10 do Gama envolvida. A avaliação será contínua, com intervalos necessários ao redirecionamento das atividades caso seja preciso, uma vez que os objetivos sejam atingidos parcialmente. Será avaliada a efetividade do aprendizado em função dos conteúdos e das abordagens metodológicas propostas, face às respostas apresentadas pelos professores e alunos. Isso, será possível a partir das observações de atitudes, competências, habilidades e procedimentos adquiridos por todos no decorrer dos trabalhos.

O projeto estará sendo acompanhado a partir das coletas de informações na Direção e Secretaria da Escola, aplicações de questionários aos alunos, conversa com professores, análise de dados e continuará à medida que for sendo viabilizado tendo em vista harmonizá-lo com o Projeto Pedagógico da Escola. Quanto a isso, pretende-se aqui, não só a aplicação do projeto à área de geografia, mas também às outras disciplinas, desenvolvendo a multidisciplinaridade dentro da escola, como nas feiras culturais que ocorrem semestralmente. É necessário também ter em mente, que esta avaliação deverá levar em conta todas as dificuldades encontradas na estruturação do projeto: estrutura física 
e humana da escola, falta de materiais pedagógicos, acesso limitado às informações na secretaria e direção da escola em função da falta de recursos humanos trabalhando. Desgaste físico e psicológico do aluno, depois de um dia de trabalho para a colaboração no preenchimento de questionários, por menos complexo que sejam. Iluminação precária e materiais didáticos indisponíveis e inacessíveis (mapas, Globos, vídeos e internet). Ou seja, será necessário, superar tanto as disfunções que atingem o acompanhamento do projeto, quanto a sua aplicabilidade e avaliação. 
11 - Referências

CARVAHO, Célia Pezzolo. Ensino Noturno. Realidade e ilusão. São Paulo . Editora Cortez. 1984 p. 112- 2a edição.

CORDEIRO, Verbena Maria Rocha, 0 ensino noturno, $2^{\circ} \mathrm{Grau}$, Configuração e relação com os trabalhadores alunos. Salvador, UFBA, 1984.

Curso de Especialização em Educação na Diversidade e Cidadania, com Ênfase em EJA disponível em WWW.fe.unb.br/eja/2010.

DISTRITO FEDERAL. Secretaria de Educação. Currículo de Educação Básica das Escolas Públicas do Distrito Federal - Brasília.

DISTRITO FEDERAL. Secretaria de Educação. Diretoria de Educação de Jovens e Adultos, Proposta de Educação de Jovens e Adultos - Brasília, 2005.

FREIRE. Paulo. Educação e Mudança. Editora Paz e terra. 1979 18ª edição.

LACOSTE, Ives,1977. A Geografia serve antes de mais nada para fazer a guerra. Lisboa: Iniciativas Editoriais. p.38. Maria Cecília França. $3^{a}$ Ed. Campinas, São Paulo; Papirus, 1993.

LIBÂNEO, José C. Democratização da Escola Pública - a Pedagogia Crítica Social dos conteúdos. São Paulo, Loyola 1985. P. 149 - 14 edição.

MOYSÉS, Lúcia $M^{\mathrm{a}}$. 1995. O Desafio de Saber Ensinar. Rio de Janeiro: Ed. da Universidade Federal Fluminense p. 36-37.

PARÂMETROS Curriculares Nacionais. Brasília, DF: MEC, Secretaria de Educação Fundamental, 1998.

PARÂMETROS Curriculares Nacionais: Terceiro e quarto ciclo: Geografia Brasília; MEC/SEF, 1998.

PINTO. Álvaro Vieira. Sete Lições sobre Educação de Adultos. Contemporânea. São

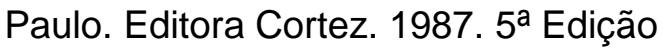


Proposta Curricular - 2 Segmento. Brasília. Ação Educativa /SEEF, 2002.

RAMOS, Marise. Possibilidades e desafios na organização do currículo integrado. In: FRIGOTTTO, Gaudêncio; CIAVATTA, Maria; RAMOS, Marise (orgs.). Ensino médio: concepção e contradições. São Paulo: Cortez, 2005. p. 106-127.

SPYER. Márcia Resende: A Geografia do Aluno Trabalhador: Caminhos para uma Prática de Ensino. São Paulo. Edições Loyola. 1986.

WEBER, Sike, Aspirações a educação: o condicionamento do modelo dominante. Petrópoles Editora Vozes. 1076 p. 142. 


\section{Anexo 1}

\begin{tabular}{|c|c|c|}
\hline \multicolumn{3}{|c|}{ Questionário direcionado ao professor do Centro de Ensino 10 do Gama. } \\
\hline & Perguntas & Respostas \\
\hline 1) & Instituição em que conclui o curso: & $\begin{array}{l}\text { CEUB } \\
1\end{array}$ \\
\hline 2) & Ano de conclusão: & 1999 \\
\hline 3) & Carga horária: & 40 horas \\
\hline 4) & Instituição de Ensino: & Centro de Ensino 10 do Gama. \\
\hline 5) & $\begin{array}{l}\text { Você conhece seus alunos, sabe } \\
\text { onde moram o que fazem durante o } \\
\text { dia? }\end{array}$ & Não, sei que muitos trabalham. \\
\hline 6) & $\begin{array}{l}\text { O que você utiliza para trabalhar os } \\
\text { conteúdos de geografia em sala de } \\
\text { aula? }\end{array}$ & $\begin{array}{l}\text { Apostila, às vezes quando a biblioteca da escola } \\
\text { quando está aberta, o livro didático para auxiliar. }\end{array}$ \\
\hline 7) & $\begin{array}{l}\text { Você utiliza livro didático? É } \\
\text { atualizado? }\end{array}$ & As vezes. Você sabe que não. \\
\hline 8) & $\begin{array}{l}\text { Você acha que o aluno da EJA. } \\
\text { consegue entender o que você esta } \\
\text { ensinando? }\end{array}$ & Acho que sim, se não explico de novo. \\
\hline 9) & $\begin{array}{l}\text { Quais as dificuldades que você } \\
\text { encontra ao trabalhar com os alunos } \\
\text { da EJA. }\end{array}$ & $\begin{array}{l}\text { Falta disposição, pré-requisito e motivação, } \\
\text { muitos estão cansados. }\end{array}$ \\
\hline 10) & Há quantos anos você leciona? & 9 anos \\
\hline 11) & $\begin{array}{l}\text { Você foi preparada para trabalhar } \\
\text { com a EJA? }\end{array}$ & $\begin{array}{l}\text { Acho que não precisa de muita experiência,com } \\
\text { exceção dos alunos da liberdade assistida,os } \\
\text { demais são tranqüilos, melhor que os do regular. }\end{array}$ \\
\hline 12) & $\begin{array}{l}\text { Você está satisfeita com o suporte } \\
\text { que a escola oferece à noite? }\end{array}$ & $\begin{array}{l}\text { Mais ou menos, minhas provas eu só consigo } \\
\text { rodar no duplicador durante o dia. }\end{array}$ \\
\hline
\end{tabular}




\begin{tabular}{|c|c|}
\hline 13) Trabalha em mais de um turno? & Sim, aqui pela manhã \\
\hline $\begin{array}{c}\text { 14) Tem tempo para planejar suas } \\
\text { aulas? }\end{array}$ & Planejo tudo pela manhã na minha coordenação. \\
\hline $\begin{array}{c}\text { 15) Como você acha que poderia } \\
\text { relacionar os conteúdos de geografia } \\
\text { com a vida dos alunos da EJA? }\end{array}$ & $\begin{array}{c}\text { Ensino a eles, para entenderem o que acontece } \\
\text { no mundo. }\end{array}$ \\
\hline $\begin{array}{c}\text { 16) Na sua opinião quais os conteúdos } \\
\text { que você encontra maior facilidade } \\
\text { em incorporar o saber geográfico e a } \\
\text { cultura de seus alunos e por quê? }\end{array}$ & $\begin{array}{c}\text { Regiões brasileiras. Porque tenho alunos de } \\
\text { várias parte do país. }\end{array}$ \\
\hline $\begin{array}{c}\text { 17) O que você acha dos conteúdos de } \\
\text { geografia ministrados na EJA. }\end{array}$ & $\begin{array}{c}\text { Ora, eu mesmo seleciono os meus. O que eu } \\
\text { posso dar durante o semestre. }\end{array}$ \\
\hline
\end{tabular}




\section{Anexo 2}

\section{Modelo de questionário dirigido ao aluno do Ensino Fundamental 10 do Gama}

Aluno:

Turma:

1. Você, aluno do Noturno, consegue relacionar o conteúdo de Geografia estudado em sala de aula com a sua experiência de vida no dia-a-dia?

2. Quais os problemas que você tem enfrentado, enquanto aluno da disciplina de geografia ao lidar com a matéria estudada?

3. Dentre os conteúdos estudados em sala, quais os que você achou mais interessantes?

4. Você consegue fazer associações entre a disciplina de geografia e as outras disciplinas?

5. Em quais conteúdos e quais disciplinas?

6. Como é que você estuda geografia? Memoriza questionários ou procura entender os assuntos?

7. Que assuntos você acha que deveriam ser abordados em geografia?

8. Consegue relacionar as outras disciplinas com a matéria de geografia?

9. Como a geografia pode Ihe ajudar com as outras matérias? 